\title{
Wage effects of job-worker mismatches: Heterogeneous skills or institutional effects?
}

Citation for published version (APA):

Allen, J. P., Badillo-Amador, L., \& van der Velden, R. K. W. (2013). Wage effects of job-worker mismatches: Heterogeneous skills or institutional effects? ROA. ROA Research Memoranda No. 021 https://doi.org/10.26481/umaror.2013021

Document status and date:

Published: 01/01/2013

DOI:

10.26481/umaror.2013021

Document Version:

Publisher's PDF, also known as Version of record

\section{Please check the document version of this publication:}

- A submitted manuscript is the version of the article upon submission and before peer-review. There can be important differences between the submitted version and the official published version of record.

People interested in the research are advised to contact the author for the final version of the publication, or visit the DOI to the publisher's website.

- The final author version and the galley proof are versions of the publication after peer review.

- The final published version features the final layout of the paper including the volume, issue and page numbers.

Link to publication

\footnotetext{
General rights rights.

- You may freely distribute the URL identifying the publication in the public portal. please follow below link for the End User Agreement:

www.umlib.nl/taverne-license

Take down policy

If you believe that this document breaches copyright please contact us at:

repository@maastrichtuniversity.nl

providing details and we will investigate your claim.
}

Copyright and moral rights for the publications made accessible in the public portal are retained by the authors and/or other copyright owners and it is a condition of accessing publications that users recognise and abide by the legal requirements associated with these

- Users may download and print one copy of any publication from the public portal for the purpose of private study or research.

- You may not further distribute the material or use it for any profit-making activity or commercial gain

If the publication is distributed under the terms of Article $25 \mathrm{fa}$ of the Dutch Copyright Act, indicated by the "Taverne" license above, 
Maastricht University

Research Centre for Education and the Labour Market | ROA

\section{Wage effects of job-worker mismatches: Heterogeneous skills or institutional effects?}

Jim Allen

Lourdes Badillo-Amador

Rolf van der Velden

\section{ROA Research Memorandum}

ROA-RM-2013/21

Research Centre for Education and the Labour Market Maastricht University

P.O. Box 616, 6200 MD Maastricht, The Netherlands

$\mathrm{T}+31433883647 \mathrm{~F}+31433884914$

secretary-roa-sbe@maastrichtuniversity.n www.roa.nl 


\title{
Wage effects of job-worker mismatches: Heterogeneous skills or institutional effects?
}

\author{
Jim Allen \\ Lourdes Badillo-Amador \\ Rolf van der Velden
}

ROA-RM-2013/21*

December 2013

Research Centre for Education and the Labour Market

Maastricht University

P.O. Box 616, 6200 MD Maastricht, The Netherlands

$\mathrm{T}+31433883647 \mathrm{~F}+31433884914$

secretary-roa-sbe@maastrichtuniversity.nl

www.roa.nl

\footnotetext{
* The ROA Research Memorandum Series was created in order to make research results available for discussion, before those results are submitted for publication in journals.
} 


\section{Abstract \\ Wage effects of job-worker mismatches: Heterogeneous skills or institutional effects?**}

The strong wage effects related to mismatches between a worker's education and that required in the job are usually attributed to assignment theory. This theory asserts that productivity and wages depend on the education-job match, which determines the utilization of skills. However, recent research shows that educational mismatches are only weakly related to skill utilization, which in any case fails to account for the bulk of the wage effects. Two alternative theories have been put forward to explain the observed wage effects. One points to wage setting institutions that cause wages to be based on job characteristics regardless of individual performance, the other to the heterogeneity of skills within a given educational level. Both theories explain existing results, but have never been tested directly. In this paper we show that the former theory explains observed wage effects in the public sector, and the latter theory those in the private sector.

JEL classification: J31, J45, J50

Keywords: wage effects, education mismatch, skill mismatch, institutional theory, heterogeneous skill theory

Jim Allen

ROA

P.O. Box 616

NL-6200 MD Maastricht

The Netherlands

j.allen@maastrichtuniversity.nl
Lourdes Badillo-Amador Universidad Politécnica de Cartagena Pza. del Cronista Isidoro Valverde Edif. La Milagrosa CP. 30202 Cartagena (Murcia) Spain lourdes.badillo@upct.es

Rolf van der Velden

ROA

P.O. Box 616

NL-6200 MD Maastricht

The Netherlands

r.vandervelden@maastrichtuniversity.nl

\footnotetext{
** The authors wish to thank Martin Humburg and Christoph Meng for their helpful comments on an earlier version of this paper.
} 


\section{Introduction}

There is strong evidence that mismatches between a worker's own education and that required in the job have strong effects on wages (Sicherman, 1991; Alba-Ramirez, 1993; Cohn and Khan, 1995; Kiker et al., 1997; Cohn and Ng, 2000; Ng, 2001; Bauer, 2002). Specifically, it has been found that workers employed in jobs requiring a lower level of education than their own (overeducated workers) are penalised in terms of wages relative to similarly educated workers working in jobs that do require that level of education (adequately educated workers) (Sicherman, 1991; Alba-Ramirez, 1993; Cohn and Khan, 1995; Kiker et al., 1997; Cohn and Ng, 2000; Ng, 2001; Bauer, 2002). These effects are usually attributed to assignment theory (Sattinger, 1993), which asserts that productivity, and thus wages, depend on the fit between education and job, which determines the degree of utilization of workers' skills. The implicit assumption hereby is that educational mismatches are accompanied by skill mismatches, and that the wage effects of educational mismatches are in fact a reflection of these skill mismatches. Recent research (Allen and Van der Velden, 2001; Di Prieto and Urwin, 2006; Green and McIntosh, 2007; McGuiness and Sloane, 2009; Chevalier and Lindley, 2009; Badillo and Vila, 2013) has cast doubt on this interpretation: educational mismatches appear to be only weakly related to skill mismatches and skill mismatches themselves do not explain the wage effects of overeducation.

Allen and Van der Velden (2001) propose two possible explanations for this anomalous finding. The first theory points to heterogeneity of skills within a given educational level, and asserts that the lower-skilled workers within each level end up in jobs for which they are formally overeducated, but not necessarily overskilled. The second explanation is rooted in the observation that wages are often not based directly on workers' productivity in the job, but come about as a result of a process of bargaining involving specific wage setting institutions. According to this theory, wages are based on job characteristics rather than skills, and skill mismatches will thus not affect wages. Both theories do equally well in explaining the fact that skill mismatches do not affect wages, but neither theory has been tested directly.

The first explanation, sometimes referred to as the heterogeneous skills within qualification levels theory (Green and McIntosh, 2007) or the heterogeneous skills theory (Di Prieto and Urwin, 2006), assumes that individuals with the same level of education can have different endowments of skills, and that workers' marketable skills determine the level of the jobs that they are able to get. According to this explanation, the reason overeducated workers earn a lower wage is because 
they have a lower level of skill, and are consequently sorted into in lower-level jobs, than their more skilled peers who find jobs at their own level.

The second explanation is rooted in the observation that wages are often not based directly on workers' productivity in the job, but come about as a result of a process of bargaining involving specific wage setting institutions. The imperfect information employers have about workers' productivity often forces them to base wages on observable characteristics such as the education level attained by a worker and that required in the job. This moves the process of wage setting from the individual to the collective level, and together with the fact that appropriate wage levels based on such criteria are frequently subject to dispute, has given rise to an extensive system of wage setting institutions in most countries in which the collective interests of workers and their employers are represented. Particularly in countries where wage levels are predominantly determined through collective bargaining, there is limited space for individual adjustments once wage scales associated with different jobs have been set down in collective bargaining agreements. As a result, overeducated workers will be rewarded according to the wage scale associated with their job, regardless of their actual level of productivity in that job. Because that job is at a lower level than jobs requiring the worker's own level of education, the overeducated worker will experience a wage penalty. ${ }^{1}$

The main objective of this paper is to test the above-mentioned theoretical perspectives, with the aim of providing an explanation for the wage discrepancies observed in the labour market between higher education graduates with similar characteristics. This research forms part of the scarce body of research which examines the wage effects of both education job-worker mismatch and skill job-worker mismatch. In addition, this paper contributes to the current literature in two different ways. First, it uses an international comparative approach, using data that is highly comparable across the countries involved. Specifically, we analyse the wage effects of job-worker mismatches for higher education graduates in nineteen European countries (Austria, Belgium, the Czech Republic, Estonia, Finland, France, Germany, Hungary, Italy, Lithuania, the Netherlands, Norway, Poland, Portugal, Slovenia, Spain, Switzerland, Turkey and the United Kingdom), and

1. Of course such bargaining processes can also result in the worker's own level of education being incorporated into wage-setting rules. However, at the aggregate level, this is not likely to appreciably change the wage levels associated with a given level of education, since a more market-based wage setting process - whether based on individual skill differences as implied by the heterogeneous skills theory or on average expected productivity of people with given levels of education as implied by signalling or screening theories - also predicts that own level of education will be rewarded on average. 
Japan. Although the analysis as such is similar to that developed in previous studies, so far there have been no such systematic international comparisons regarding the wage effects of job-worker mismatches. The second and most important contribution to the literature is more theoretical. By considering differences between various countries in the degree of heterogeneity of skills within higher education and the strength of wage setting institutions, this article tests for the first time the two different theories that have been put forward to explain the fact that skill mismatches do not affect wages: the heterogeneous skill theory and the institutional theory.

The results show that the former theory best explains the strength of the effects of educational mismatches in the private sector, whereas the latter theory accounts more for the strength of effects in the public sector. This suggests that quite different wage setting mechanisms operate in the private and public sectors, with private sector wages being based more on relative skill levels of adequately educated versus overeducated workers, while public sector wages are based more on rules.

This paper is divided into six sections. Section 2 describes the main hypotheses that are tested in the paper. Section 3 describes the data and variables used in this study. In Section 4 we present the models used. Section 5 shows the results and, finally, Section 6 discusses the implications of our findings.

\section{Hypotheses}

Both the theories outlined in the previous section account for the anomalous wage effects associated with educational and skill mismatches, but the arguments are completely different. So far, research has failed to determine which, if any, of these two theories is correct. A direct test would require accurate individual-level data on actual skill levels. If the heterogeneous skills theory is correct, we would expect the wage effects of educational mismatches to be fully accounted for by workers' actual skill levels. ${ }^{2}$ If the wage effects could not be accounted for by skills, this would lend credence to the institutional explanation.

Unfortunately, accurate and objective data on skill levels and applicable wage scales are not readily available at this time in data sets which also include measures of educational mismatches

2. This explanation implies that there are in fact no skill mismatches driving wage effects of educational mismatches as the assignment theory implies, but rather differences in skill levels. 
at the individual level. It is however possible to test these theories indirectly by comparing countries.

If the wage effects are mainly due to institutional wage setting arrangements, we should expect wages to be more strongly based on observable characteristics, such as the education level attained by a worker and that required in the job, in countries in which wage setting is more strongly institutionalized. There is however an asymmetry in how such institutional arrangements can be expected to affect returns to workers' own level of education on one hand and returns to required or appropriate level of education on the other. Rules prescribing that a worker's own level of education be directly incorporated into wage scales will mainly have the effect of institutionalizing existing market-based effects of acquired level of education, shifting them somewhat from the individual to the aggregate level, but having little effect on wages at the aggregate level. By contrast, rules prescribing that the level of the job be directly incorporated into wage scales will have a strong and visible effect, also at the aggregate level (recalling that skill utilization differences - which would be the main market-based reason for expecting job levels to be reflected in wages, net of individual skill levels - have been shown not to account for these effects). The net expected effect is for stronger effects of educational mismatches in countries in which wage setting is more strongly institutionalized, and weaker effects in countries in which wages are more market-based.

There is also some scope for testing the heterogeneous skill theory by means of an international comparison, although the reasoning here is a little more complex. If wage effects of overeducation are due to differences in skill levels, it follows that these effects will be strongest in countries where the skill difference between overeducated and adequately educated workers is greatest. Although we have no direct measure of these skill differences, we can make inferences about their relative size from available information on distribution of supply of and demand for skilled labour, more specifically the proportion jobs requiring a high level of education, and the supply of labour with that level of education.

The difference in skill level between adequately educated and overeducated workers will depend in the first place on how strongly workers with differing levels of skill are sorted between the two groups. Given the distribution of skills among workers with a given level of education, skillbased sorting of applicants between jobs requiring at least that level and jobs requiring a lower level of education will result in larger skill differences in countries where there are fewer jobs in 
the latter category. The reason for this is that the smaller the proportion of jobs in which workers are overeducated, the more the workers employed in these jobs will be restricted to the extreme lower tail of the skill distribution. Figure 1 illustrates this. ${ }^{3}$

Figure 1 Effect of proportion of overeducated workers in a country on the mean skill difference between adequately educated and overeducated workers in countries with the same skill distribution

country A:

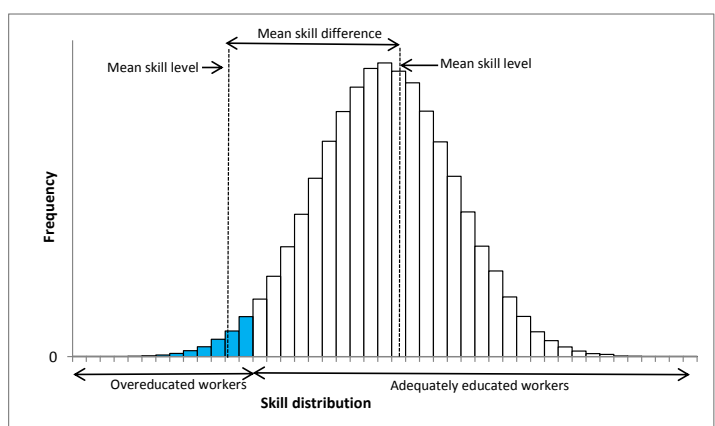

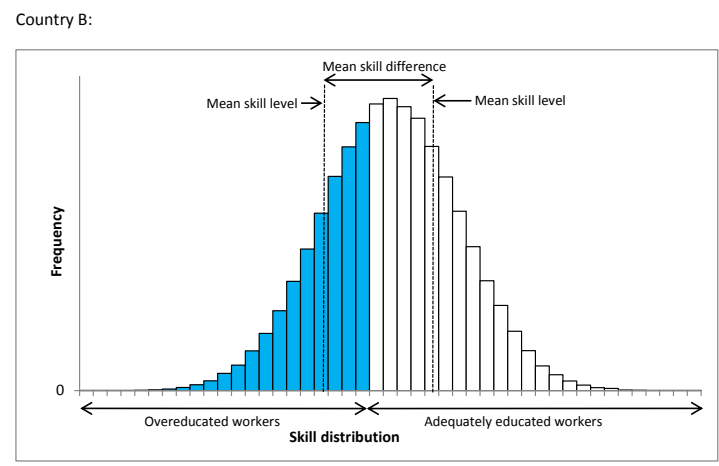

Figure 1 shows the sorting process in two countries in which graduates are sorted in a similar fashion into "good jobs" (jobs requiring one's own level of education) and "bad jobs" (jobs requiring a lower level of education), the only difference being that in country B there are more low level jobs (jobs in which workers are overeducated). Figure 1 shows that, all other things being equal, there are larger skill differences between adequately educated and overeducated workers when the latter form a smaller proportion of the population. This is simply the result of the fact that in that case the "bad jobs" will be more strongly concentrated at the lower end of the skill distribution than would be the case when there are more "bad jobs". If skills drive productivity and productivity drives wages, we would expect stronger wage effects of overeducation in country A than in country B.

We stated above that the only difference between country A and country B was in the proportion of "bad jobs". Of course, in reality countries will differ in more respects than this, and this may also have an impact on the size of the average skill difference between adequately educated and

3. In theory it is also possible that greater differences between adequately educated and overeducated workers will arise in some countries simply because employers in those countries have a stronger preference for sorting according to perceived skills than their counterparts in other countries. However, there is no reason to expect such differences in preferences to be systematically linked to differences between countries in the way education and/or work are organized. For example, even in countries with highly institutionalized wage-setting processes, employers will have a strong incentive to select the best workers for the best jobs. 
overeducated workers. In particular, the overall skill distribution among workers with a given level of education may be broader in some countries than in others. Figure 2 illustrates this.

Figure 2 Effect of differences in skill distribution between countries on the mean skill difference between adequately educated and overeducated workers

Country C:

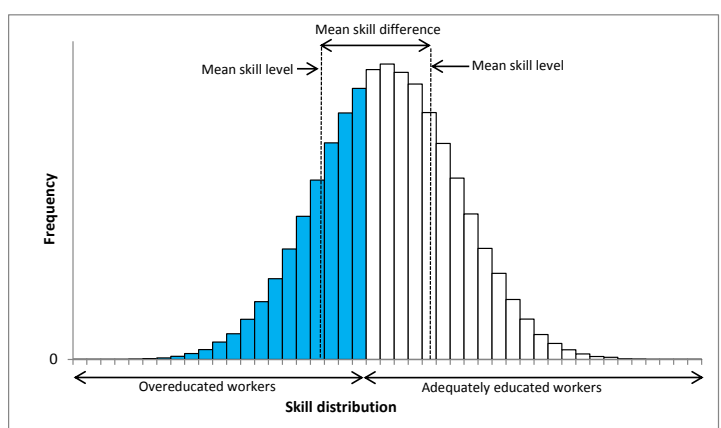

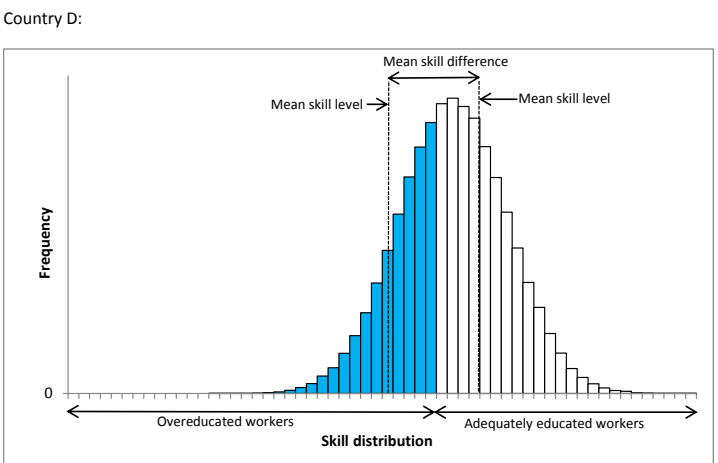

In both countries workers queue in the same manner for the same number of good jobs. But because of the broader skills distribution in country $\mathrm{C}$, the average skill difference between adequately educated and overeducated workers will be larger than in country D. If skills drive productivity and productivity drives wages, we would expect stronger wage effects of overeducation in country $\mathrm{C}$ than in country $\mathrm{D} .^{4}$

What could give rise to differences in the breadth of the skill distribution? Keeping in mind that we are considering higher education graduates, the primary factor that we would expect to influence this is the degree of selectivity of the higher education system, reflected in the proportion of the relevant age cohort that completes higher education. The larger this proportion, the more people with a less than excellent level of natural ability will complete higher education, and consequently the broader the skill distribution among higher education graduated will be.

4. Of course this queuing model is a simplification with respect to reality, but this will not affect the predictions of the model. In reality we would expect different degrees of overeducation (jobs requiring only slightly less education than one has, jobs requiring quite a bit less education and jobs requiring little or no education at all). These would all differ more from each other the broader the skills distribution. In reality the sorting will also be less than perfect, so that some overeducated workers will have higher skill levels than some adequately educated workers, but this will also not change the basic predictions of the model. In fact we would expect more of these "misallocations" in the case of a compressed skill distribution than when skills are more varied, the skill difference between two adjacent workers in the queue will be smaller and more difficult to distinguish. This will serve to further reduce the differences between adequately educated and overeducated workers. 
Combining the two perspectives, we come to the prediction that the wage effect of overeducation will be greatest in countries with little overeducation and a non-selective higher education system (country A), and smallest in countries with much overeducation and a selective higher education system (country D). Countries with little overeducation and a selective higher education system (country B) and countries with much overeducation and a non-selective higher education system (country C) will occupy an intermediate position.

These considerations give rise to the following hypotheses:

Hypothesis 1: educational mismatches are associated with stronger effects on wages in countries with stronger wage setting institutions than in countries with a more market-based wage setting system.

Hypothesis 2: educational mismatches are associated with weaker effects on wages in countries with more selective higher education systems and a high incidence of graduate overeducation than in countries with less selective higher education systems and little graduate overeducation.

Confirmation of Hypothesis 1 would imply empirical support for the institutional explanation, while confirmation of Hypothesis 2 would imply support for the heterogeneous skill theory. The two theories are of course not mutually exclusive, and it is possible, at least in theory, that both are confirmed.

We will test these two hypotheses at the level of countries as a whole, and also separately for the public and private sectors. The public-private sector distinction may be important because of the strong theoretical and empirical evidence for the existence of different mechanisms for wage determination between one sector and the other (see for example Gyourko and Tracy, 1988; Hartog and Oosterbeek, 1993; Dustmann and van Soest, 1998; Gregory and Borland, 1999).

In general we would expect employers in the private sector to be more attuned to differences in productivity when selecting and allocating labour and determining wage levels than their counterparts in the public sector. This is due to the relative absence of objective performance or output indicators that could be used to calibrate wage levels at either the individual or organisational level. Because of this relative lack of objective performance indicators, we would expect wage setting in the public sector to be relatively rule-based, even in the absence of a strong influence of external wage-setting institutions. Consequently, we would expect relatively little to change in the public sector when such institutions become more influential. This gives rise to the 
expectation that collective bargaining will have relatively little impact on the wage effects of educational mismatches in the public sector.

By contrast, in the private sector, employers will be strongly motivated to adjust wages as much as possible to actual productivity. Consequently, they have little or no incentive to apply fixed wage scales for particular jobs unless external pressure is applied forcing them to do so. In the absence of strong wage-setting institutions there is no such pressure, but when institutions become more influential, fixed wage scales for jobs will be more prevalent. This gives rise to the expectation that collective bargaining will have a relatively strong impact on the wage effects of educational mismatches in the private sector.

We would also expect the above-mentioned differences between the public and private sectors to affect the impact of heterogeneous skills on the severity of wage penalties of overeducation. Simply stated, if private sector employers are more attuned to productivity differences than their public sector counterparts, they will be more responsive to increasing differences in mean skill level between adequately educated and overeducated workers. Consequently, we would expect wage penalties associated with overeducation to be more responsive to increasing skill heterogeneity in the private sector than in the public sector.

In sum, we expect both effects to be stronger in the private than in the public sector:

Hypothesis 1b: stronger wage setting institutions will have a stronger effect on the wage effect of educational mismatches in the private than in the public sector.

Hypothesis 2b: more selective higher education systems and a high incidence of graduate overeducation will have a stronger effect on the wage effect of educational mismatches in the private than in the public sector.

\section{Data and variables}

In order to be able to compare effects across countries, it is important that the data used are strictly comparable. Differences in the operationalization of key variables could give rise to spurious differences between countries, or mask or reduce differences that really exist. The main data used in this article come from a single data set based on a uniform research design. We use data on twenty countries (Austria, Belgium, the Czech Republic, Estonia, Finland, France, Germany, Hungary, Italy, Japan, Lithuania, the Netherlands, Norway, Poland, Portugal, Slovenia, 
Spain, Switzerland, Turkey and the United Kingdom). Most of these countries took part in the international project 'The Flexible Professional in the Knowledge Society' (REFLEX). The data from the REFLEX project were collected in the spring of 2005 by means of mail questionnaires ${ }^{5}$ and are focused on graduates who obtained a higher education degree in the academic year 1999/2000. Five countries, namely Hungary, Lithuania, Poland, Slovenia and Turkey, took part in the project 'Higher Education as a Generator of Strategic Competences' (HEGESCO), which used the same methodology as REFLEX for a survey conducted in 2008 among graduates of the academic year 2002/2003. ${ }^{6}$

The samples used in this study include wage-earners who work between 16 and 60 contract hours per week in their main employment and are between 25-40 years old. They exclude those who increased their education level after finishing the study programme in the reference year (1999/2000 in the case of REFLEX, 2002/2003 in the case of HEGESCO), were studying at the moment of the interview, and those who had less than 3 years of labour market experience because of participation in further studies. In addition, graduates born outside the country in question are excluded.

\subsection{Job-worker mismatch}

In order to determine the incidence and extent of education job-worker mismatches, the required education level for each job has been identified on the basis of graduates' answers to the following question: 'What type of education do you feel is most appropriate for [your current] work?' The answer categories correspond to different levels of education in each country, both at tertiary level and below. The answers to this question have been recoded into estimated years of education required to achieve this level. By comparing the answers to this question with the years of education associated with the level of education attained by the graduate (also included in the analysis as a control variable), it was possible to derive a measure for the number of years of overeducation (whereby cases where the graduates' own level of education is lower than that required for the job have been recoded to zero).

5. The REFLEX project is funded by the EU 6th Framework Program (Contract No: CIT2-CT-2004-506352) and several national funds. More detailed information regarding the REFLEX project can be found on the following web page: http://www.reflexproject.org .

6. The HEGESCO project has been funded by the EU Erasmus program (133838-LLP-1-2007-1-SIERASMUS-EMHE) and several national funds. More detailed information regarding the HEGESCO project can be found on the following web page: http://www.hegesco.org . 
Figure 3 provides a sketch of the extent of overeducation by country. ${ }^{7}$ To illustrate the importance of using years of overeducation in the analysis rather than a simple binary measure (overeducated yes/no), both measures are included in the figure. Although the ordering of countries is roughly similar according to both measures, there are some striking differences. For example, although Austria has a below-average proportion of overeducated graduates, it shows the fourth highest level of overeducation in terms of mean years of overeducation. The reason for this discrepancy is the high proportion of Austrian graduates - more than $10 \%$ - with 5 years of overeducation. In contrast, overeducation is much more common in France, but is usually less severe, with less than $0.5 \%$ of French graduates being overeducated by five years or more.

\section{Figure 3 Overeducation per country}

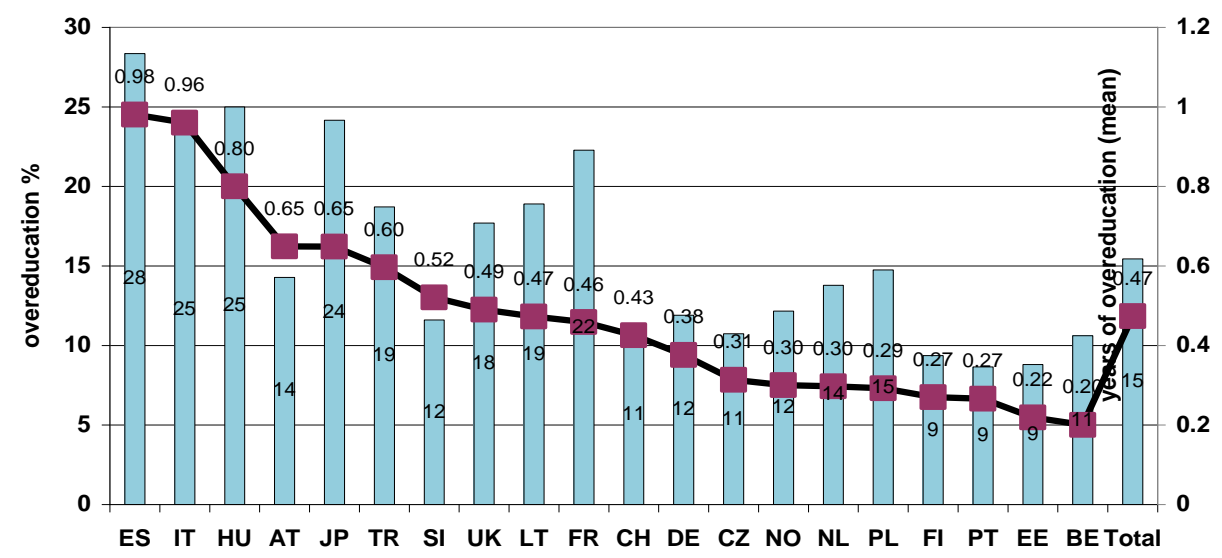

$\square$ overeducated $\quad-$ mean years of overeducation

In addition to this indicator of mismatch in terms of level of education, we also include an indicator of skill surplus. This indicator consists of the respondents' answers to the question: "To what extent are your knowledge and skills utilized in your current work?" The original answers were reported on a five-point scale ranging from 1 ("not at all") to 5 ("to a very high extent"). The scale was recoded into the reverse order to create an indicator of the degree of skill surplus.

7. The countries are as follows: Italy (IT), Austria (AT), Spain (ES), Hungary (HU), Turkey (TR), Slovenia (SI), Germany (DE), Czech Republic (CZ), Japan (JP), Lithuania (LT), France (FR), Switzerland (CH), Belgium (BE), United Kingdom (UK), Portugal (PT), Estonia (EE), Poland (PL), Finland(FI), Netherlands (NL), and Norway (NO). 


\subsection{Country level variables}

As stated above, we include two country level variables to test our main hypotheses. The first of these is the level of collective bargaining coverage in a country, that is the percentage of workers in a country covered by collective agreements on terms of employment between representatives of employers' and employees. This will be used as an indicator of the strength of wage-setting institutions ${ }^{8}$ and relates to the institutional theory. We use collective bargaining coverage rather than union density because the former is generally viewed as more indicative of the overall influence of institutions on wage setting in a country than the latter.

The second variable relates to the skills heterogeneity theory and consists - as we argued earlier in section 2 - of a combination of two measures, the incidence of overeducation and the degree of skill heterogeneity in a country. The former measure has already been presented in Figure 3: the mean number of years of overeducation. The latter measure is operationalized in terms of the percentage of people between 24-35 years old in a country with an ISCED 5A degree. ${ }^{9}$ In countries where this percentage is small, this indicates that access to higher education is limited. In such countries we would expect the skill levels of the graduate population to be more homogeneous than in countries with fewer barriers to access to higher education, where the percentage of the youth cohort with a tertiary degree is higher.

There are various ways in which we could combine the two measures, and the results appear quite robust to the precise specification. ${ }^{10}$ We wanted a measure that would show a high value for countries with relatively little overeducation and a relatively non-selective system of higher education, a low value for countries where the opposite applies, and an intermediate value in all other cases. The method we chose was simply to rescale both indicators so that countries vary on each of these scales on a range from 0.1 to 1 , then simply to subtract the converted score on overeducation from that on heterogeneity. The resulting score is less sensitive to extreme values on either component variable than for example a score based on the ratio of one component to the other, and can vary maximally between -1 and +1 (in reality it varies somewhat less). We call the resulting indicator 'relative heterogeneity'. Table 1 shows the two components in their original form, the rescaled components, and the resulting score per country, which is simply the difference between the rescaled components.

8. See OECD (2004) for OECD countries, and Fulton (2007) for Estonia.

9. See OECD (2007) for OECD countries, and Statistics Estonia (2006).

10. We tried several specifications and the results are substantially the same regardless of the specification. 
Table 1 Selectivity of higher education, mean years of overeducation, and relative heterogeneity index per country

\begin{tabular}{|c|c|c|c|c|c|}
\hline & \multicolumn{2}{|c|}{ Youth cohort in HE } & \multicolumn{2}{|c|}{ Years of overeducation } & \multirow{2}{*}{$\begin{array}{r}\text { Relative } \\
\text { heterogeneity index } \\
(\mathrm{H}-\mathrm{O})\end{array}$} \\
\hline & $\%$ & rescaled $(\mathrm{H})$ & mean & rescaled $(\mathrm{O})$ & \\
\hline Italy & 18 & 0.19 & 0.96 & 0.97 & -0.79 \\
\hline Austria & 13 & 0.01 & 0.65 & 0.58 & -0.57 \\
\hline Spain & 26 & 0.47 & 0.98 & 1.00 & -0.53 \\
\hline Hungary & 21 & 0.29 & 0.80 & 0.77 & -0.48 \\
\hline Turkey & 14 & 0.05 & 0.60 & 0.51 & -0.47 \\
\hline Slovenia & 18 & 0.19 & 0.52 & 0.42 & -0.23 \\
\hline Germany & 16 & 0.12 & 0.38 & 0.23 & -0.12 \\
\hline Czech Republic & 15 & 0.08 & 0.31 & 0.15 & -0.07 \\
\hline Japan & 29 & 0.58 & 0.65 & 0.58 & 0.00 \\
\hline Lithuania & 24 & 0.40 & 0.47 & 0.36 & 0.04 \\
\hline France & 24 & 0.40 & 0.46 & 0.34 & 0.06 \\
\hline Switzerland & 26 & 0.47 & 0.43 & 0.30 & 0.17 \\
\hline Belgium & 18 & 0.19 & 0.20 & 0.01 & 0.18 \\
\hline United Kingdom & 29 & 0.58 & 0.49 & 0.38 & 0.20 \\
\hline Portugal & 21 & 0.29 & 0.27 & 0.09 & 0.20 \\
\hline Estonia & 25 & 0.43 & 0.22 & 0.03 & 0.40 \\
\hline Poland & 30 & 0.61 & 0.29 & 0.13 & 0.48 \\
\hline Finland & 32 & 0.68 & 0.27 & 0.10 & 0.58 \\
\hline Netherlands & 35 & 0.79 & 0.30 & 0.13 & 0.65 \\
\hline Norway & 41 & 1.00 & 0.30 & 0.14 & 0.86 \\
\hline
\end{tabular}

Several countries - notably Italy, Austria, Spain and Hungary - combine a low percentage of the youth cohort in higher education with a high incidence of overeducation, and are consequently assigned a low value on the relative heterogeneity index. Hypothesis 2 predicts relatively low wage penalties for overeducation in these countries. Conversely, several countries - notably Norway, the Netherlands, Finland and Poland - combine a high percentage of the youth cohort in higher education with a low incidence of overeducation, and are consequently assigned a high value on the relative heterogeneity index. Hypothesis 2 predicts relatively high wage penalties for overeducation in these countries. Countries with an intermediate score on the index consist of countries with a similar rank on both measures, including countries such as Japan that score relatively highly on both measures, countries such as Belgium that show a relatively low score on both measures, and countries such as Lithuania that occupy an intermediate position on both measures. 
Figure 4 plots the percentage of collective bargaining coverage against the relative heterogeneity index per country.

Figure 3 Collective bargaining and relative heterogeneity per country

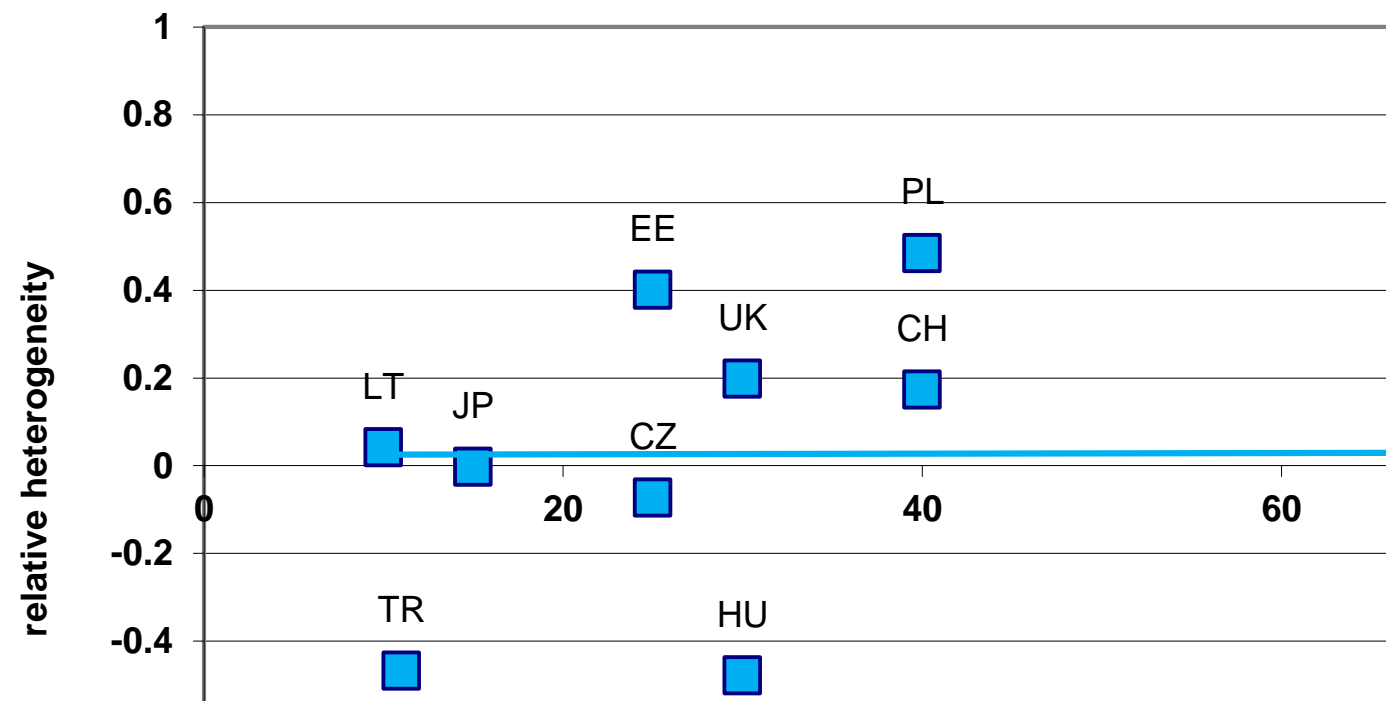

As the blue regression line in Figure 3 makes clear, countries vary quite independently on these two dimensions, which is favourable for testing our hypotheses.

\section{Model}

To examine the wage effect of job-worker mismatches, we estimate five multi-level (random coefficient) models, in which data on individual graduates (i) is nested within countries (j). As dependent variable we use standardized log wage. The reason for standardizing the wage measure is to avoid a possible complication with respect to the testing of Hypothesis 1. Stronger wagesetting institutions (usually heavily influenced by trade unions) are not only expected to increase the chance that formal characteristics of workers and jobs are incorporated into wage scales, but are also widely believed to contribute to wage compression across the board. If so, this would reduce all observed wage effects, including those associated with educational mismatch. Any such effect would tend to mask the effect of institutionalizing the wage-setting process per se, which after all is about how workers with given observable characteristics are assigned a place in 
the existing wage distribution rather than about how that distribution comes into being. By standardizing log wage separately for each country we avoid this complication. ${ }^{11}$

In the first model we include the effects of overeducation and a vector of control variables:

$$
z(\text { Lnwage })_{i j}=\alpha_{0 i j}+O V E R E D_{i j} \alpha_{1}+X_{i j} \alpha_{2}
$$

where:

$$
\alpha_{0 i j}=\alpha_{0}+\mu_{0 j}+\varepsilon_{0 i j}
$$

Equation (2) indicates that the intercept $\alpha_{0 \mathrm{ij}}$ is decomposed into an overall mean across all countries $\left(\alpha_{0}\right)$, an error term or variance at the country level $\left(\mu_{0 \mathrm{j}}\right)$ and an error term or variance at the individual level $\varepsilon_{0 \mathrm{ij}}$ ). The control variables included are: two dummy variables on work experience during higher education (distinguishing study-related and non study-related experience), months of work experience since graduation, gender, age, and degree level in higher education (converted into an interval level variable indicating the number of years of higher education normally required to achieve that level), and a dummy variable distinguishing employment in the public versus private sector. ${ }^{12}$

Strictly speaking, for the purposes of our analyses, skill utilization is also a control variable. However, to test whether the findings of previous research cited in the introduction - that effects of overeducation are not attributable to underutilization of skills - are replicated in our data, we add the indicator of skill surplus described in Section 3.1 in a separate step (model 2):

$$
z(\text { Lnwage })_{i j}=\alpha_{0 i j}+\text { OVERED }{ }_{i j} \alpha_{1}+S K I L L S U R P_{i j} \alpha_{2}+X_{i j} \alpha_{3}
$$

with the same specification for $\alpha_{0 \mathrm{ij}}$ as above. The residual effect of overeducation after controlling for skill surplus is the effect we are interested in here. This is the part of the effect of overeducation that is not accounted for by an assignment explanation, since it is not due to a mismatch of skills as assignment theory would suggest. In order to be able to test our hypotheses, it is necessary that this residual effect of overeducation should vary significantly between countries. Consequently, in the next model we partition the effect of overeducation into an overall

11. Note that standardising the wages per country also eliminates any need to make wages comparable using a PPP conversion.

12. To avoid unnecessary loss of cases we replaced missing values on control variables by zero in the case of dummy variables and the country mean in the case of continuous variables. To prevent biased results, in both cases we included dummies to indicate that the data was missing. 
mean effect across countries and a random country-level variance component. The model (model 3) then becomes:

$z(\text { Lnwage })_{i j}=\alpha_{0 i j}+O V E R E D_{i j} \alpha_{1 j}+S K I L L S U R P_{i j} \alpha_{2}+X_{i j} \alpha_{3}$

where $\alpha_{0 \mathrm{ij}}$ is as specified above in equation (2) and:

$\alpha_{1 j}=\alpha_{1}+\mu_{1 j}$

To test to what extent the wage effect of overeducation varies with the extent of collective bargaining and/or relative heterogeneity in a country, the respective country level variables are then added to the model, together with interactions with overeducation (model 4$)^{13}$

$z(\text { Lnwage })_{i j}=\alpha_{0 i j}+$ OVERED $\alpha_{i j} \alpha_{1 j}+S K I L L S U R P_{i j} \alpha_{2}+$ CBARGAIN $_{i j} \alpha_{3}+$ CBARGAIN $*$ OVERED $_{i j} \alpha_{4}$ + RELHET $_{i j} \alpha_{5}+$ RELHET $^{*}$ OVERED ${ }_{i j} \alpha_{6}+X_{i j} \alpha_{7}$

We estimate each of these sets of models first of all for the full sample in each country. We subsequently estimated the full model (model 4) separately for the public and private sectors.

\section{Results}

The results of the analyses at the level of countries as a whole are shown in Table 2. Looking first at the results of model 1 in this table we see that, as expected, there is a strong effect of overeducation. Since the dependent variable is standardized $(\log )$ wages, this means that each year of overeducation is associated with a reduction in $(\log )$ wages of around 0.18 standard deviations. The effects of all the control variables are significant and all have the expected signs. Of particular note are the effects of years of education and of working in the public as opposed to the private sector. Each additional year of education is associated with an additional 0.22 standard deviations in $(\log )$ wages, which - as expected - is slightly more than the shift associated with

13. In order to check the robustness of the effects, separate models were also estimated in which these country-level variables were included separately. The effects - both main effects and interactions with overeducation - proved highly robust, so only the combined model is reported here. Results of the separate models are available on request from the authors. 
years of overeducation cited above. Working in the public sector is associated with a reduction of 0.23 standard deviations in (log)wages compared to comparable workers in the private sector, which is also in line with what we expected. This may be an indication that wage determination processes are different in the public and private sectors. As such, it provides some preliminary justification for our decision to specify separate models for the two sectors (see below). ${ }^{14}$

Table 2 Estimated coefficients from multi-level analyses, general model ${ }^{\mathbf{1 5}}$

\begin{tabular}{|c|c|c|c|c|c|c|c|c|}
\hline & $\begin{array}{r}\text { Model } \\
1\end{array}$ & & Model 2 & & $\begin{array}{r}\text { Model } \\
3\end{array}$ & & $\begin{array}{r}\text { Model } \\
4\end{array}$ & \\
\hline Intercept & -1.794 & $* * *$ & -1.666 & $* * *$ & -1.667 & $* * *$ & -1.672 & $* * *$ \\
\hline Years of overeducation & -0.179 & $* * *$ & -0.163 & $* * *$ & -0.184 & $* * *$ & -0.123 & $* * *$ \\
\hline Skill surplus & & & -0.053 & $* * *$ & -0.047 & $* * *$ & -0.047 & $* * *$ \\
\hline Collective bargaining coverage & & & & & & & 0.000 & \\
\hline Overeducation $*$ coll. barg. coverage & & & & & & & -0.001 & $*$ \\
\hline Relative heterogeneity & & & & & & & 0.071 & \\
\hline Overeducation*rel. heterogeneity & & & & & & & -0.052 & \\
\hline Control variables & yes & & yes & & yes & & yes & \\
\hline \multicolumn{9}{|l|}{ Country level variance } \\
\hline Intercept & 0.018 & $* * *$ & 0.018 & $* * *$ & 0.026 & $* * *$ & 0.025 & $* * *$ \\
\hline Years of overeducation & & & & & 0.007 & $* * *$ & 0.006 & $* * *$ \\
\hline \multicolumn{9}{|l|}{ Individual level variance: } \\
\hline Intercept & 0.850 & $* * *$ & 0.848 & $* * *$ & 0.841 & $* * *$ & 0.841 & $* * *$ \\
\hline$-2 *$ Log likelihood & 62023.8 & & 61954.1 & & 61805.9 & & 61798.5 & \\
\hline Change in $-2 *$ Log likelihood & $3678.8 \mathrm{a}$ & $* * *$ & 69.7 & $* * *$ & 148.2 & $* * *$ & 7.4 & \\
\hline \multicolumn{9}{|l|}{$* * *$ significant at $1 \%$ level } \\
\hline \multicolumn{9}{|l|}{$* *$ Significant at $5 \%$ level } \\
\hline \multicolumn{9}{|l|}{$*$ significant at $10 \%$ level } \\
\hline Note a: compared to "empty" model ex & & & & & & & & \\
\hline
\end{tabular}

When the skill surplus indicator is added in model 2, we see that there is also a strong negative effect. However, controlling for underutilization only marginally changes the effect of overeducation. This replicates of the results of earlier studies by Allen and Van der Velden and others, and confirms that the effects of overeducation do not appear to be explained by the assignment theory.

14. It is of course possible that the public-private sector differential indicates unobserved ability or productivity differences. Such a sorting process would in itself constitute evidence that the two segments of the labour market operate according to somewhat different principles.

15. See Appendix 1 for full results. 
In model 3 we add the country-level variance in the effect of overeducation. We can see that this effect indeed varies significantly across countries, resulting in a strong improvement in the model fit (as seen in the decrease in -2Log likelihood).

In column 4, the indicators of collective bargaining and relative heterogeneity are added. Both interactions show the expected signs (we expected the wage penalty of overeducation to be greater in countries with respectively higher levels of collective bargaining coverage (hypothesis 1) and in countries with a higher degree of relative skills heterogeneity (hypothesis 2). However, only the interaction between collective bargaining and overeducation is (weakly) statistically significant. $^{16}$

Figure 4 Relation between the level of collective bargaining coverage in a country and the posterior mean of the wage effect of overeducation.

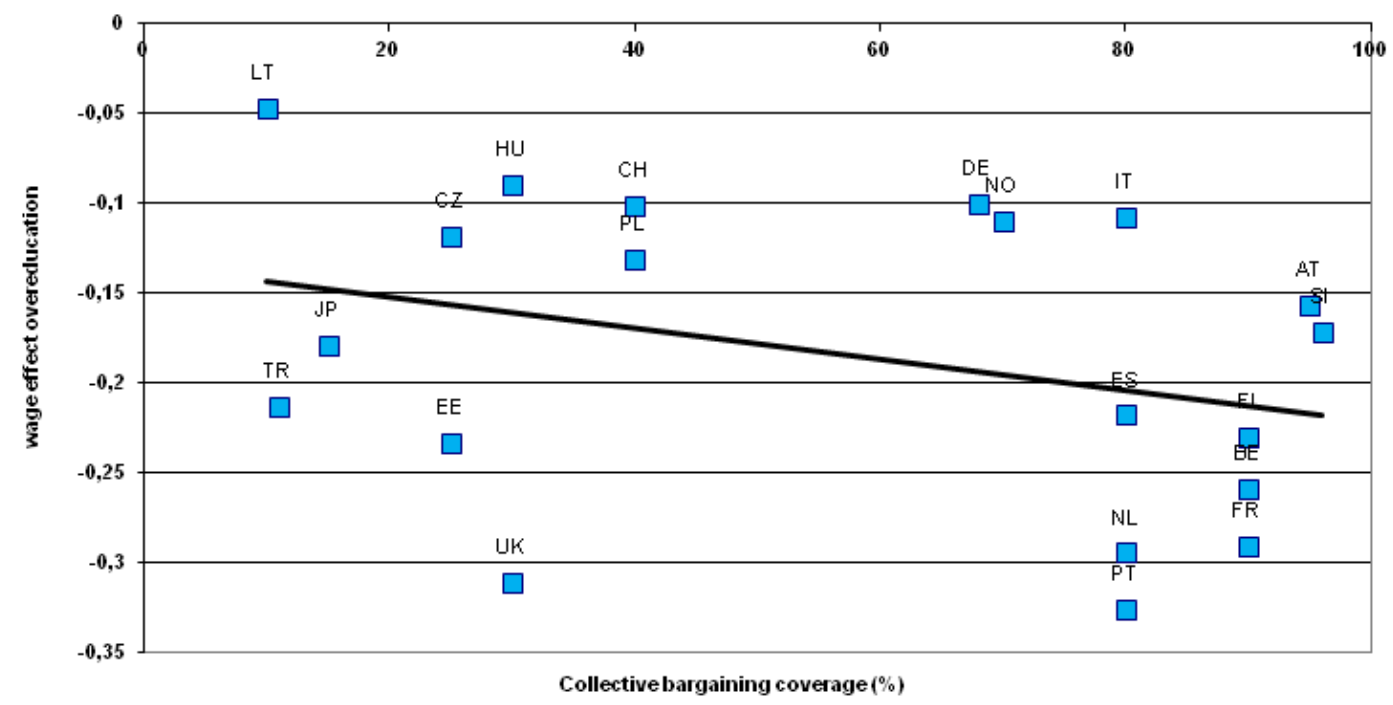

To give a more comprehensive picture of these relationships, Figures 4 and 5 show how the socalled posterior country means of the wage effect of overeducation (on which the country-level variance in this effect is based) and the two predictor variables. These are the posterior means for model three, before inclusion of these predictors.

16. This also applies when the two variables are included separately. The pattern of effects is robust to the specific group of countries included. For example, even when all the new EU member states are 
The slight negative slope in Figure 4 confirms what we saw already in Table 1, namely that there is a (weakly significant) relation between collective bargaining and the wage effect of overeducation. Many countries conform to the expected pattern (for example, the Netherlands and Portugal combine a high level of collective bargaining coverage with strong negative effects of overeducation, while Lithuania, the Czech Republic and Hungary have low levels of collective bargaining and a very weak negative effect of overeducation). However, because a number of countries run counter to this expected relation, the effect is only weakly significant. In particular the UK and Estonia, with their relatively low levels of collective bargaining but strong wage effects of overeducation, and Norway, Germany and Italy, where strong collective wage bargaining fails to result in strong wage effects of overeducation, do not fit the expected pattern.

Figure 5 Relation between the level of relative heterogeneity in a country and the posterior mean of the wage effect of overeducation.

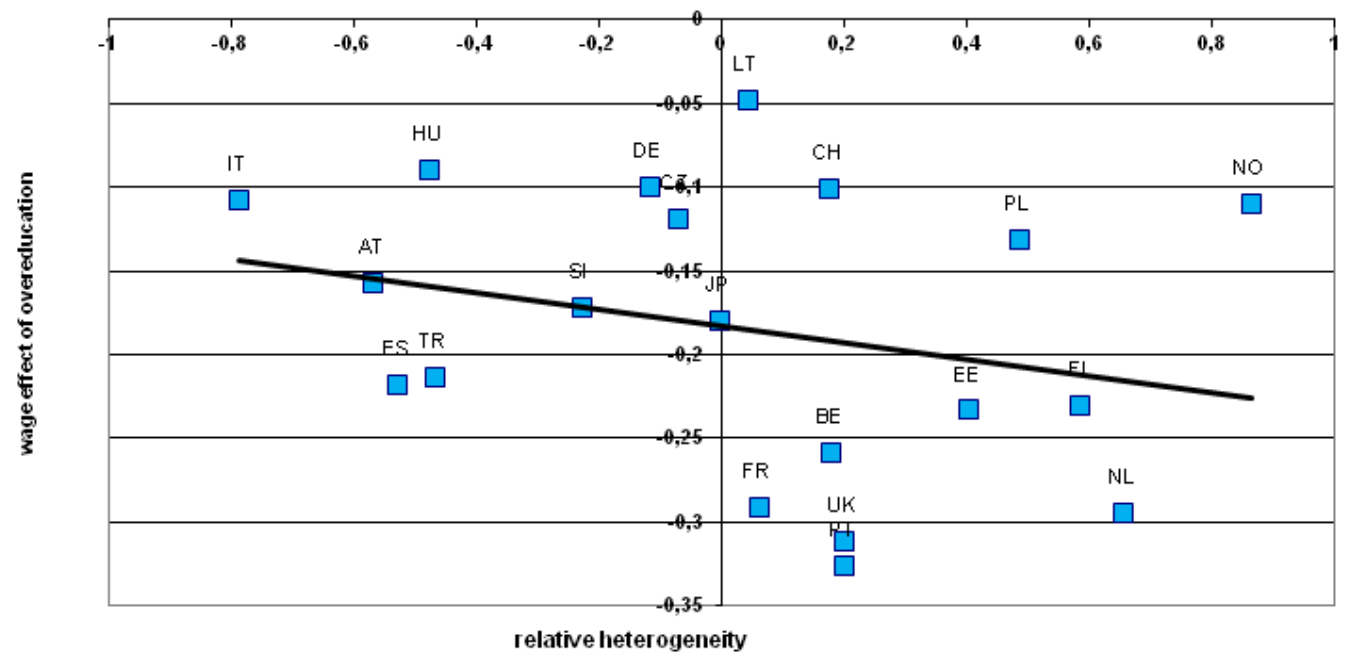

Figure 5 reveals a similar picture for relative heterogeneity. Again, many countries fit the expected pattern - for example the Netherlands, Finland and Estonia on one hand, which combine high levels of relative heterogeneity with strong negative wage effects of overeducation, and Italy, Hungary and Austria, where both relative heterogeneity and wage penalties associated with overeducation are low. Again however, several countries fail to conform to this pattern - for example Norway, the UK, and Portugal - which in this case prevents the effect from reaching even weak levels of significance.

excluded from the graph, the pattern remains essentially the same. This applies to all the models 
Where does this leave us? Although there are some indications in support of both hypotheses, the effects are weak and in the case of relative heterogeneity not even significant at $10 \%$ level. At the level of countries as a whole we cannot claim that either hypothesis is convincingly confirmed. However, as mentioned above, there is reason to believe that wage formation is controlled by somewhat different forces in the private than in the public sector. In order to test hypotheses $1 \mathrm{~b}$ and $2 \mathrm{~b}$, we estimate the effects separately for the two segments of the labour market. Table 3 shows the equivalent effects to the estimates shown in columns 3 and 4 of Table 2, separately for the private and the public sectors.

Table 3 Estimated coefficients from multi-level analyses, private and public sector models ${ }^{17}$

\begin{tabular}{|c|c|c|c|c|c|c|c|c|}
\hline & \multicolumn{4}{|c|}{ Private sector } & \multicolumn{4}{|c|}{ Public sector } \\
\hline & \multicolumn{2}{|c|}{ Model 3} & \multicolumn{2}{|l|}{ Model 4} & \multicolumn{2}{|c|}{ Model 3} & \multicolumn{2}{|c|}{ Model 4} \\
\hline & B & & & B & B & & B & \\
\hline Intercept & $-1,660$ & $* * *$ & $-1,610$ & $* * *$ & $-2,107$ & $* * *$ & $-2,202$ & $* * *$ \\
\hline Years of overeducation & $-0,197$ & $* * *$ & $-0,161$ & $* * *$ & $-0,150$ & $* * *$ & $-0,044$ & \\
\hline Skill surplus & $-0,045$ & $* * *$ & $-0,045$ & & $-0,038$ & $* * *$ & $-0,039$ & $* * *$ \\
\hline Collective bargaining coverage & & & $-0,001$ & & & & 0,002 & \\
\hline Overeducation*coll. barg. Coverage & & & $-0,001$ & & & & $-0,002$ & $* * *$ \\
\hline Relative heterogeneity & & & 0,215 & $* * *$ & & & $-0,126$ & \\
\hline Overeducation*rel. heterogeneity & & & $-0,092$ & $* * *$ & & & $-0,044$ & \\
\hline Control variables & yes & & yes & & yes & & yes & \\
\hline \multicolumn{9}{|l|}{ Country level variance } \\
\hline \multicolumn{9}{|l|}{ Intercept } \\
\hline Years of overeducation & 0,024 & $* * *$ & 0,014 & $* * *$ & 0,075 & $* * *$ & 0,070 & $* * *$ \\
\hline Individual level variance: & 0,006 & $* * *$ & 0,004 & $* *$ & 0,009 & $* *$ & 0,005 & $* *$ \\
\hline \multicolumn{9}{|l|}{ Intercept } \\
\hline & 0,861 & $* * *$ & 0,861 & $* * *$ & 0,757 & $* * *$ & 0,757 & $* * *$ \\
\hline$-2 *$ Log likelihood & 37937.5 & & 37922.2 & & 23325.7 & & 23314.8 & \\
\hline Change in $-2 *$ Log likelihood & 2691.5 & $* * *$ & 15.5 & $* * *$ & 1024.9 & $* * *$ & 10.9 & $* *$ \\
\hline \multicolumn{9}{|l|}{$* * *$ significant at $1 \%$ level } \\
\hline \multicolumn{9}{|l|}{$* *$ Significant at $5 \%$ level } \\
\hline * significant at $10 \%$ level & & & & & & & & \\
\hline
\end{tabular}

estimated in this paper.

17. See Appendix 2 for full results. 
When we look at the separate results for the private and public sector, we see a strongly different pattern of results. First of all, model 3 shows that there is a somewhat stronger wage penalty for overeducation in the private sector than in the public sector, which is what we would expect if wages are more compressed in the public sector. Model 4 for the private sector model shows a strongly significant negative interaction between relative heterogeneity and the effect of overeducation, suggesting that the wage penalty in the private sector is stronger in countries where HE graduates' skills are varied and overeducation is rare. This is illustrated in Figure 6, which is again based on the so-called posterior means for the effect of overeducation prior to including the country-level predictors in the model.

Figure 6 Relation between the level of relative heterogeneity in a country and the posterior mean of the wage effect of overeducation, private versus public sectors.

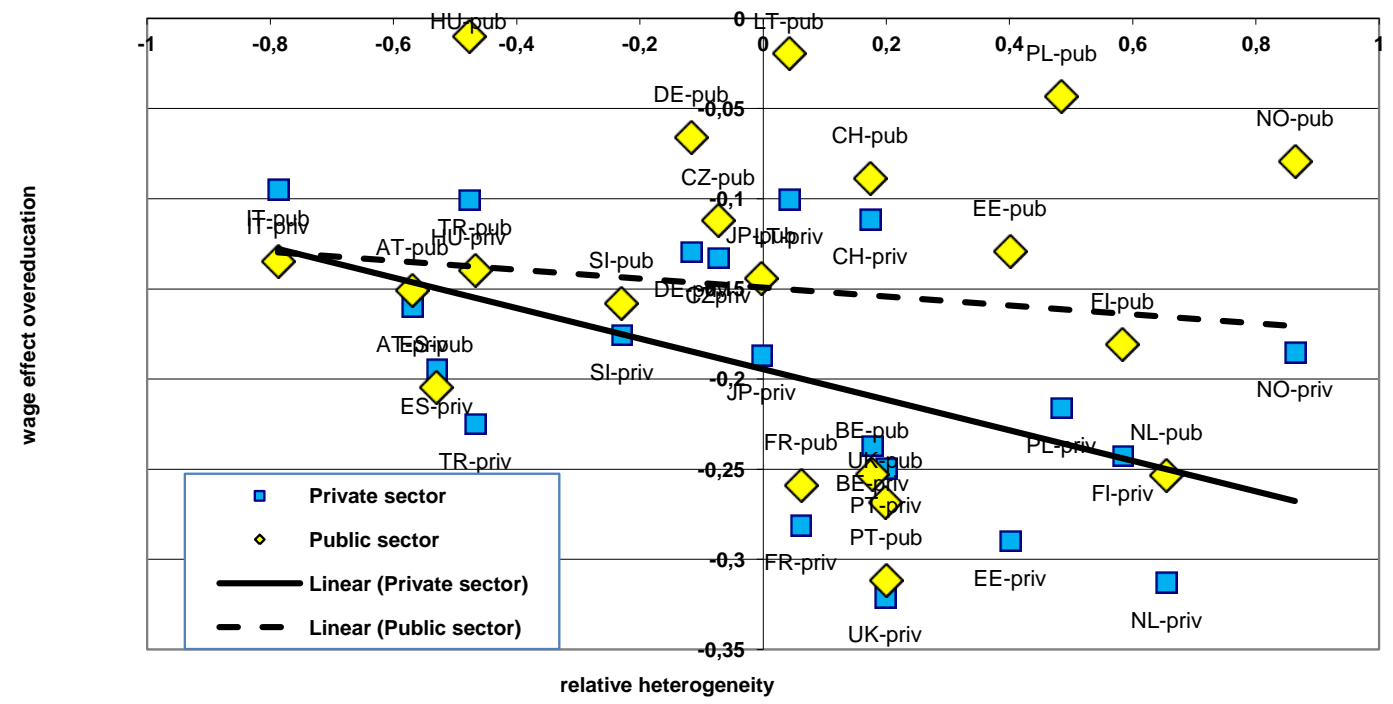

Figure 6 makes clear that wage setting processes are quite different in the public versus the private sector. As we already saw in Table 3, the wage penalty of overeducation is weaker in the public sector than in the private sector in almost all countries. It seems that when graduates find employment in the public sector they are somewhat shielded from the severest wage penalties when they are overeducated. By contrast, in the private sector, the highest rewards are reserved for relative 'high-flyers', which would be more likely to have work matching their level of education than less valued workers. 
These general differences between the public and private sector are consistent with the view that private sector wages ware more market-based, rewarding workers on the basis of their productivity, whereas this applies much less to public sector wages. It seems likely that overeducated workers in the public sector are paid higher wages than one would expect based on their productivity. This view is further enhanced by the finding that the private-sector wage effects of overeducation are especially strong in countries with high levels of relative heterogeneity. If, as expected, private sector wages are more based on productivity than in the public sector, this is exactly what we would expect to see. By contrast, although there are also strong differences between countries in the wage effects of overeducation in the public sector - in fact, the overall variation is considerably greater than in the private sector - these are hardly related to relative heterogeneity. This is also exactly what we would expect if wages are less productivity-based in the public sector than they are in the private sector. In sum: the heterogeneous skills theory - which predicts that the differential wage effects of overeducation can be accounted for by skill differences between overeducated and adequately educated workers - finds support, but only in the private sector.

By contrast, Hypothesis $2 b$, which predicts that stronger wage setting institutions will have a stronger effect on the wage effect of educational mismatches in the private than in the public sector, is not supported by our results. On the contrary, as Table 3 makes clear, in the public sector wage effects of overeducation are more strongly related to collective bargaining coverage than they are in the private sector. There is a strongly significant negative interaction between collective bargaining coverage and the effect of overeducation, suggesting that the wage penalty in the public sector is stronger in countries where there is a high level of collective bargaining coverage than in countries with lower levels of collective bargaining coverage. This is shown in Figure 7. 
Figure 7 Relation between the level of collective bargaining coverage in a country and the posterior mean of the wage effect of overeducation, private versus public sectors.

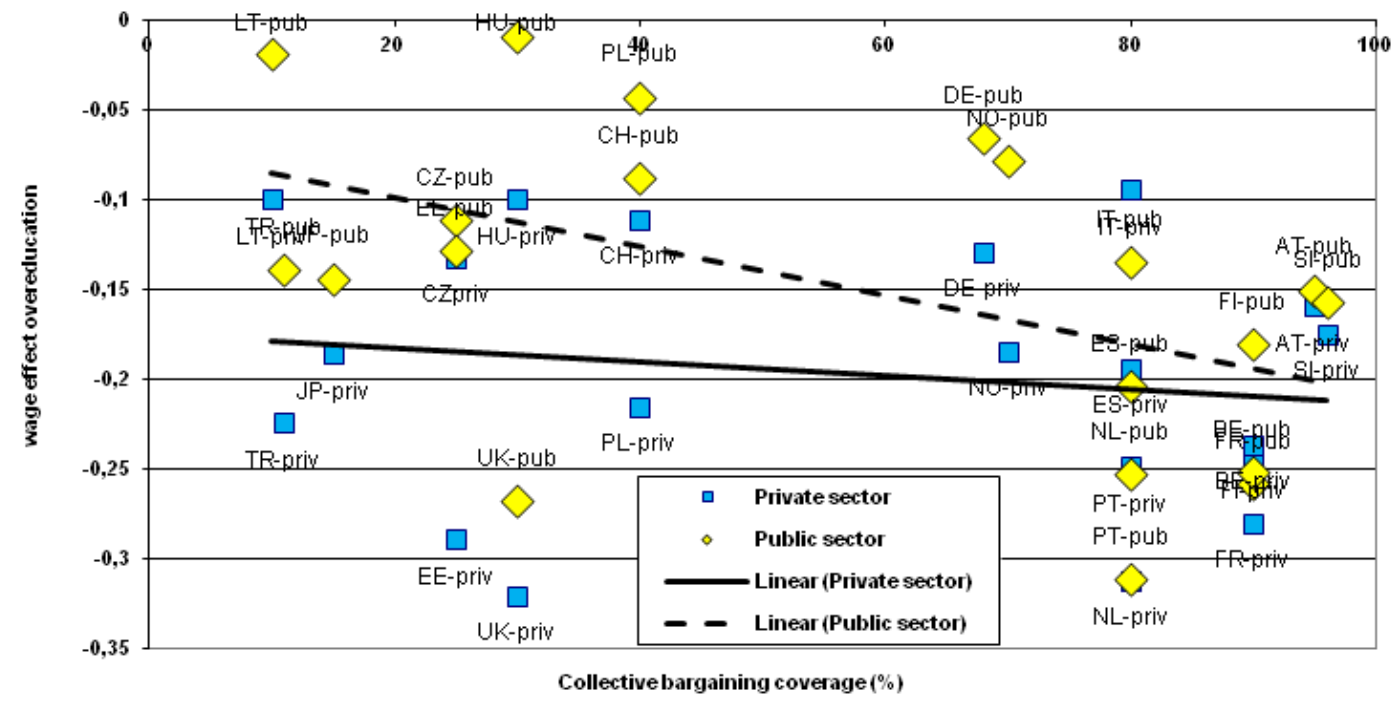

Figure 7 illustrates the clear relation between collective bargaining coverage and the wage effects of overeducation in the public sector, and the virtual absence of such a relation in the private sector. This is precisely the opposite to what we expected.

How can we account for this unexpected result? To begin with, recall that our expectation of stronger influence of wage-setting institutions in the private than in the public sector was based on the expectation that wage setting in the public sector will always be relatively rule-based, even in the absence of a strong influence of external wage-setting institutions. As a result, we expected relatively little to change in the public sector when such institutions become more influential. By contrast, we expected rules to play a limited role in the private sector in the absence of strong wage setting institutions, which led to the expectation that such institutions would have an especially strong effect in the private sector.

A possible - although at this point speculative - explanation for this apparent anomaly is that external wage-setting institutions have a strong effect on the nature of the rules governing wagesetting processes in the public sector. When there are high levels of collective bargaining, these rules are likely to come into being under influence of trade unions, which we might expect to strive to institutionalize wage entitlements in the form of wage scales associated with particular types of jobs. In the absence of such an influence, we might expect the rules to be somewhat more arbitrary, because in that case public sector employers are guided by neither objective 
performance indicators nor trade unions or similar other institutions possessing specialized knowledge of appropriate pay levels. If it is indeed the case that pay rules are more arbitrary, this would have the effect of eroding the difference in average wage levels between overeducated and adequately educated workers.

The institutional theory thus finds support, but only in the public sector. However, the absence of such an effect of collective bargaining coverage in the private sector does not necessarily mean that this has literally no effect there. It is to be expected that unions are no less insistent on wage scales in the private sector than in the public sector. However, as we saw in Figure 5, private sector employers are more inclined than their public sector counterparts to penalize overeducated workers in any case, based on actual productivity differences. So the main effect of institutionalized wage scales in the private sector will be to shift these wage penalties from the individual to the aggregate level.

\section{Conclusions}

Our point of departure in this paper was the finding in recent research that the wage effects of overeducation that are usually attributed to assignment theory cannot, as the theory implies, be explained in terms of skill mismatches. We examined two possible explanations for this anomalous finding. The first explanation is rooted in the observation that wages are often not based directly on workers' productivity in the job, but come about as a result of a process of bargaining involving specific wage setting institutions. According to this theory wages are based on job characteristics rather than skills and skill mismatches will thus not affect the wages. The second theory points to heterogeneity of skills within a given educational level and asserts that the low-skilled in each level wind up in jobs for which they are formally overeducated, but not necessarily overskilled. Both theories do equally well in explaining the fact that skill mismatches do not affect wages, but until now have never been tested directly.

In this paper we have put both of these theories to the test, using an international database containing data on recent higher education graduates in 20 countries. To test the theory that the effects are due to the influence of wage setting institutions, we looked at whether the effects of educational mismatches are stronger in countries in which wage setting is more strongly institutionalized, and weaker in countries in which wages are more market-based. To test the theory that the effects are due to skill differences between adequately educated and overeducated 
workers, we looked at whether the effects are stronger in countries in which there is a greater heterogeneity of skills, and in which the proportion of overeducated workers is low. Under such circumstances, we would expect that overeducated workers would be strongly located in the left tail of the skills distribution, and would therefore be clearly less skilled on average than adequately educated workers. In the opposite case, when skills are homogeneous and there is a high proportion of overeducated workers, the overeducated workers will be represented across a broader range of the skills distribution, which is in any case more narrow. This will mean that the skill differences between adequately educated and overeducated workers will be relatively small.

Our results provide support for both of these theories. However, in both cases the support only applies to a given segment of the labour market. In the private sector, the wage effects of overeducation are best accounted for by the relative heterogeneity of skills in the population of young higher educated workers. This finding is consistent with our hypothesis that wage setting is more strongly based on productivity - the actual skill level of workers - in the private sector than in the public sector. By contrast, in the public sector, these effects seem to be better accounted for by the strength of wage setting institutions. In contrast to our hypothesized effect, it seems that the effect of wage setting institutions is not rendered redundant by the fact that wage setting is already strongly based on rules in the public sector. On the contrary: the influence of wage setting institutions is far more profound in the public sector. A possible explanation for this apparent anomaly is that such institutions transform the logic underlying wage-setting rules, resulting in a more systematic relation between wages and job levels in the public sector, where, in the absence of such institutions, wage setting processes are more arbitrary. Paradoxically, the transformation is much less profound in the private sector, where wage-setting institutions mainly shift wage penalties from the individual to the aggregate level. 


\section{References}

Alba-Ramírez, A. (1993) Mismatch in the Spain labour market: Overeducation?, Journal of Human Resources, 28, 259-278.

Allen, J. and van der Velden, R. (2001) Educational mismatches versus skill mismatches: Effects on wage, job satisfaction, and on-the-job search, Oxford Economic Papers, 53, 434-452.

Badillo-Amador, L. and Vila, E. (2013) Education and skill mismatches: wage and satisfaction consequences, International Journal of Manpower, Vol. 34 Iss: 5, pp.416 - 428.

Bauer, T.K. (2002) Educational Mismatch and Wages: a Panel Analysis, Economics of Education Review, 21, 221-229.

Chevalier, A. and Lindley, J. (2009) Overeducation and the skills of UK graduates, Journal of the Royal Statistical Society, Series A, 172, 307-337.

Cohn, E. and Ng, Y.C. (2000) Incidence and wage effects of overschooling and underschooling in Hong Kong, Economics of Education Review, 19, 159-168.

Cohn, E. and Khan, S.P. (1995) The wage effects of overschooling revisited, Labour Economics, 2, 67-76.

Di Pietro, G. and Urwin, P. (2006). Education and skills mismatch in the Italian graduate labour market, Applied Economics, 38, 79-93.

Dustmann, C. and van Soest, A. (1998) Public and private sector wages of male workers in Germany, European Economic Review, 42, 1417-1441

Fulton, L. (2007) Worker representation in Europe, Labour Research Department and ETUIREHS.

Gregory, R.G. and Borland, J. (1999) Recent developments in public sector labor markets, in O.C. Ashenfelter and D. Card (ed.) Handbook of Labor Economics, Volume 3, Part 2, 3573 3630

Green, F. and McIntosh, S. (2007) Is There a genuine under-utilization of skills amongst the overqualified?, Applied Economics, 39, 427-439.

Gyourko, J. and Tracy, J. (1988) An analysis of public- and private-sector wages allowing for endogenous choices of both government and union status, Journal of Labor Economics, 6, 229-253

Hartog, J. and Oosterbeek, H. (1993) Public and private sector wages in the Netherlands, European Economic Review, 37, 97-114

Kiker, B.F., Santos, M.C. and De Oliveira, M.M. (1997) Overeducation and undereducation: Evidence for Portugal, Economics of Education Review, 16(2): 111-125. 
McGuinness, S. and Sloane, P.J. (2009), Labour market mismatch among UK graduates: An analysis using REFLEX data, Discussion Paper No 4168, IZA, Mannheim.

Ng, Y.C. (2001) Overeducation and undereducation and their effect on earnings: Evidence from Hong Kong, 1986-1996, Pacific Economic Review, 6, 401-418.

OECD (2004) Employment Outlook, OECD, Paris.

OECD (2007) Education at a Glance, OECD, Paris.

Sattinger, M. (1993) Assignment Models of the Distribution of Earnings, Journal of Economic Literature, 31, 831-880.

Sicherman, N. (1991) "Overeducation" in the Labour Market, Journal of Labour Economics, 9, $101-122$.

Statistics Estonia (2006) Estonian LFS. 


\section{Appendix 1 Estimated coefficients from multi-level analyses, general model}

\begin{tabular}{|c|c|c|c|c|c|c|c|c|c|c|c|c|}
\hline & $\mathrm{B}$ & & $S E$ & B & & $S E$ & B & & $S E$ & B & & $S E$ \\
\hline Intercept & -1.794 & $\star \star \star *$ & 0.093 & -1.666 & $\star \star \star *$ & 0.094 & -1.667 & $* * *$ & 0.096 & -1.672 & 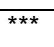 & 0.115 \\
\hline Years of overeducation & -0.179 & *** & 0.005 & -0.163 & *** & 0.005 & -0.184 & $* * *$ & 0.020 & -0.123 & *** & 0.038 \\
\hline Skill surplus & & & & -0.053 & *** & 0.006 & -0.047 & $* * *$ & 0.006 & -0.047 & *** & 0.006 \\
\hline Months employed since graduation & 0.011 & *** & 0.001 & 0.011 & *** & 0.001 & 0.011 & $* \star *$ & 0.001 & 0.011 & *** & 0.001 \\
\hline Study-related work experience before graduation & 0.003 & *** & 0.000 & 0.002 & *** & 0.000 & 0.002 & $* * *$ & 0.000 & 0.002 & *** & 0.000 \\
\hline Non study-related work experience before graduation & 0.001 & *** & 0.000 & 0.001 & *** & 0.000 & 0.001 & $* \star *$ & 0.000 & 0.001 & *** & 0.000 \\
\hline Gender: female & -0.311 & *** & 0.013 & -0.314 & *** & 0.013 & -0.315 & $\star * *$ & 0.013 & -0.315 & *** & 0.013 \\
\hline Age in years & 0.019 & *** & 0.003 & 0.019 & *** & 0.003 & 0.019 & $\star \star \star *$ & 0.003 & 0.019 & *** & 0.003 \\
\hline Years of higher education & 0.220 & *** & 0.008 & 0.218 & *** & 0.008 & 0.219 & $* * *$ & 0.008 & 0.220 & *** & 0.008 \\
\hline Public sector & -0.225 & *** & 0.013 & -0.234 & *** & 0.013 & -0.230 & $\star * *$ & 0.013 & -0.230 & *** & 0.013 \\
\hline Missing: Months employed since graduation & -0.155 & *** & 0.023 & -0.151 & *** & 0.023 & -0.152 & *** & 0.023 & -0.151 & *** & 0.023 \\
\hline Missing: Study-related work experience before graduation & 0.146 & & 0.092 & 0.144 & & 0.091 & 0.139 & & 0.091 & 0.139 & & 0.091 \\
\hline Missing: Non study-related work experience before graduation & 0.000 & & 0.000 & 0.000 & & 0.000 & 0.000 & & 0.000 & 0.000 & & 0.000 \\
\hline Missing: Gender & -0.098 & & 0.065 & -0.100 & & 0.065 & -0.098 & & 0.064 & -0.101 & & 0.064 \\
\hline Missing: Age in years & -0.028 & & 0.064 & -0.022 & & 0.064 & -0.017 & & 0.064 & -0.014 & & 0.064 \\
\hline Missing: public/private sector & -0.174 & *** & 0.054 & -0.161 & *** & 0.055 & -0.154 & *** & 0.055 & -0.154 & *** & 0.055 \\
\hline Missing: skill surplus & & & & -0.156 & & 0.107 & -0.161 & & 0.107 & -0.162 & & 0.107 \\
\hline Collective bargaining coverage & & & & & & & & & & 0.000 & & 0.001 \\
\hline Years of overeducation $X$ collective bargaining coverage & & & & & & & & & & -0.001 & * & 0.001 \\
\hline Relative heterogeneity & & & & & & & & & & 0.071 & & 0.083 \\
\hline Years of overeducation $\mathrm{X}$ relative heterogeneity & & & & & & & & & & -0.052 & & 0.041 \\
\hline \multicolumn{13}{|l|}{ Country level variance } \\
\hline Intercept & 0.018 & *** & 0.006 & 0.01801 & *** & 0.01 & 0.026 & $* * *$ & 0.008 & 0.025 & *** & 0.008 \\
\hline Years of overeducation & & & & & & & 0.007 & $* * *$ & 0.003 & 0.006 & *** & 0.002 \\
\hline \multicolumn{13}{|l|}{ Individual level variance: } \\
\hline Intercept & 0.850 & *** & 0.008 & 0.8478 & $\star * *$ & 0.01 & 0.841 & $* * *$ & 0.008 & 0.841 & $* * *$ & 0.008 \\
\hline$-2^{\star}$ Log likelihood & 62023.8 & & & 61954.1 & & & 61805.9 & & & 61798.5 & & \\
\hline Change in $-2^{*}$ Log likelihood & 3678.8 & *** & & 69.7 & *** & & 148.2 & $\star \star \star *$ & & 7.4 & & \\
\hline
\end{tabular}

** Significant at $5 \%$ level

* significant at $10 \%$ level 
Appendix 2 Estimated coefficients from multi-level analyses, private and public sector models

\begin{tabular}{|c|c|c|c|c|c|c|c|c|c|c|c|c|}
\hline & \multicolumn{6}{|c|}{ Private sector } & \multicolumn{6}{|c|}{ Public sector } \\
\hline & $\mathrm{B}$ & & $S E$ & $\mathrm{~B}$ & & SE & $\mathrm{B}$ & & SE & B & & SE \\
\hline Intercept & $-1,660$ & *** & 0,126 & $-1,610$ & *** & 0,131 & $-2,107$ & $* * *$ & 0,141 & $-2,202$ & *** & 0,178 \\
\hline Years of overeducation & $-0,197$ & *** & 0,019 & $-0,161$ & *** & 0,034 & $-0,150$ & $* * *$ & 0,024 & $-0,044$ & & 0,041 \\
\hline Skill surplus & $-0,045$ & *** & 0,008 & $-0,045$ & & 0,008 & $-0,038$ & $* \star *$ & 0,010 & $-0,039$ & *** & 0,010 \\
\hline Months employed since graduation & 0,014 & *** & 0,001 & 0,013 & *** & 0,001 & 0,008 & $* * *$ & 0,001 & 0,008 & *** & 0,001 \\
\hline Study-related work experience before graduation & 0,003 & *** & 0,000 & 0,003 & *** & 0,000 & 0,001 & $* * *$ & 0,000 & 0,001 & $* * *$ & 0,000 \\
\hline Non study-related work experience before graduation & 0,002 & *** & 0,000 & 0,002 & *** & 0,000 & 0,000 & & 0,000 & 0,000 & & 0,000 \\
\hline Gender: female & $-0,373$ & *** & 0,016 & $-0,373$ & *** & 0,016 & $-0,192$ & *** & 0,020 & $-0,191$ & *** & 0,020 \\
\hline Age in years & 0,011 & *** & 0,004 & 0,011 & *** & 0,004 & 0,031 & $* * *$ & 0,004 & 0,032 & *** & 0,004 \\
\hline Years of higher education & 0,245 & *** & 0,011 & 0,246 & *** & 0,010 & 0,196 & $* * *$ & 0,012 & 0,195 & $* * *$ & 0,012 \\
\hline Missing: Months employed since graduation & $-0,135$ & *** & 0,030 & $-0,135$ & *** & 0,030 & $-0,165$ & $* * *$ & 0,034 & $-0,165$ & *** & 0,034 \\
\hline Missing: Study-related work experience before graduation & 0,036 & & 0,132 & 0,033 & & 0,132 & 0,297 & ** & 0,121 & 0,299 & ** & 0,121 \\
\hline Missing: Non study-related work experience before graduation & 0,000 & & 0,000 & 0,000 & & 0,000 & 0,000 & & 0,000 & 0,000 & & 0,000 \\
\hline Missing: Gender & $-0,093$ & & 0,076 & $-0,094$ & & 0,076 & $-0,189$ & & 0,114 & $-0,186$ & & 0,114 \\
\hline Missing: Age in years & $-0,057$ & & 0,079 & $-0,055$ & & 0,079 & 0,105 & & 0,106 & 0,105 & & 0,106 \\
\hline Missing: skill surplus & $-0,301$ & ** & 0,127 & $-0,302$ & ** & 0,127 & 0,061 & & 0,187 & 0,064 & & 0,187 \\
\hline Collective bargaining coverage & & & & $-0,001$ & & 0,001 & & & & 0,002 & & 0,002 \\
\hline Years of overeducation $X$ collective bargaining coverage & & & & $-0,001$ & & 0,001 & & & & $-0,002$ & *** & 0,001 \\
\hline Relative heterogeneity & & & & 0,215 & *** & 0,065 & & & & $-0,126$ & & 0,139 \\
\hline Years of overeducation $\mathrm{X}$ relative heterogeneity & & & & $-0,092$ & *** & 0,036 & & & & $-0,044$ & & 0,043 \\
\hline \multicolumn{13}{|l|}{ Country level variance } \\
\hline Intercept & 0,024 & *** & 0,008 & 0,014 & *** & 0,005 & 0,075 & $* * *$ & 0,025 & 0,070 & $* * *$ & 0,023 \\
\hline Years of overeducation & 0,006 & *** & 0,002 & 0,004 & ** & 0,002 & 0,009 & ** & 0,003 & 0,005 & ** & 0,002 \\
\hline \multicolumn{13}{|l|}{ Individual level variance: } \\
\hline Intercept & 0,861 & *** & 0,010 & 0,861 & *** & 0,010 & 0,757 & $* * *$ & 0,011 & 0,757 & $* * *$ & 0,011 \\
\hline$-2^{*}$ Log likelihood & 37937.5 & & & 37922.2 & & & 23325.7 & & & 23314.8 & & \\
\hline Change in $-2^{*}$ Log likelihood & 2691.5 & *** & & 15.5 & *** & & 1024.9 & $* * *$ & & 10.9 & ** & \\
\hline
\end{tabular}

$\frac{\text { Change in }-2 * \text { Log likelihood }}{* * *}$ significant at $1 \%$ level

** Significant at $5 \%$ level

${ }^{*}$ significant at $10 \%$ level 